\title{
Diversity and chromosomal evolution in the genus Ancistrus Kner, 1854 (Loricariidae: Ancistrini) from three hydrographic basins of Mato Grosso State, Brazil
}

\author{
Sandra Mariotto ${ }^{1}$, Liano Centofante ${ }^{2}$ and Orlando Moreira-Filho ${ }^{3}$
}

Cytogenetic analyses were carried out in 117 specimens of seven species of the genus Ancistrus from three hydrographic in Mato Grosso State: Paraguay, Araguaia-Tocantins and Amazon basins. Conventional cytogenetic techniques were used to obtain mitotic chromosomes. C-banding was performed to detect heterochromatic regions and silver nitrate staining was used to identify nucleolar organizer regions (Ag-NORs). The counted and paired chromosomes revealed diploid numbers ranging from $2 n=40$ to $2 n=54$ with karyotype formulae varying from $F N=80$ to $F N=86$. Single marks in distinct chromosomes identified the nucleolar organizer regions. The constitutive heterochromatin was scarce in the diploid number from $2 \mathrm{n}=50$ to $2 \mathrm{n}=54$ and conspicuous blocks were observed in a single species with $2 \mathrm{n}=40$ chromosomes. These data corroborate the hypotheses of reduction of diploid number in species with derived features such as presence of sex chromosomes and polymorphisms, besides allowing inferences about the evolutionary mechanisms and the ancestor karyotype that favored the diversification of this important genus in the tribe Ancistrini.

Foram realizadas análises citogenéticas de 117 espécimes do gênero Ancistrus de três bacias hidrográficas do estado de Mato Grosso: Paraguai, Araguaia-Tocantins e Amazônica, utilizando as técnicas de citogenética convencional para obtenção de cromossomos mitóticos, visualização de regiões heterocromáticas e regiões organizadoras de nucléolos. Os cromossomos pareados revelaram uma variação no número diploide de $2 \mathrm{n}=40$ a $2 \mathrm{n}=54$ e número fundamental de $\mathrm{NF}=80$ a $\mathrm{NF}=86$. As regiões organizadoras de nucléolos foram evidenciadas em um único par de cromossomos para todas as espécies e a heterocromatina é escassa nas espécies com números diploides elevados $(2 n=50$ a $2 n=54)$. Os blocos heterocromáticos mais evidentes foram observados nos pares portadores das AgRONs e em cromossomos da espécie com $2 \mathrm{n}=40$. Estes dados contribuem para a hipótese de redução do número diploide nas espécies que apresentam polimorfismos cromossômicos e cromossomos sexuais, além de contribuir para inferências sobre os mecanismos de evolução cariotípica que favoreceu a diversificação do gênero Ancistrus, o mais representativo na tribo Ancistrini.

Key words: AgNOR, Cytogenetic, Diploid number, Heterochromatin.

\section{Introduction}

The genus Ancistrus comprises small fish, up to $15 \mathrm{~cm}$ in total length, characterized by a large and compressed body covered with dermal plates, including some species with several long coetaneous tentacles (Burgess, 1989). Amongst Loricariidae, Ancistrus ranks second in the number of species (59 described ones), right after Hypostomus (Ferraris, 2007). The species of this genus are regarded as more derived than the other 26 genera reported in the tribe Ancistrini, a sistergroup of Pterygoplichthini (Armbruster, 1997, 2004).
The high karyotype diversity is found in Ancistrus species, whose diploid number ranges from $2 n=34$ to 52 chromosomes, including simple and multiple sex chromosome systems and chromosomal polymorphisms (Artoni \& Bertollo, 2001; Mariotto et al., 2004; Mariotto \& Miyazawa, 2006; de Oliveira et al., 2008; Mariotto et al., 2009).

Chromosomal rearrangements, such as fusions, pericentric and paracentric inversions, heterochromatin accumulation and/or translocations have played a major role in the karyotype evolution and diversification of some freshwater fish groups from Neotropical region (Giuliano-Caetano, 1998;

${ }^{1}$ Instituto Federal de Educação Ciência e tecnologia de Mato Grosso (IFMT), campus Bela Vista. Rua Juliano Costa Marques s/n, Bela Vista, 78050-560 Cuiabá, MT, Brazil. mariottodolina@bol.com.br

${ }^{2}$ Universidade Federal do Mato Grosso, Instituto de Biociências, Laboratório de Citogenética e Genética Animal. Rua Fernando Correa da Costa, 2367, 78060-900 Cuiabá, MT, Brazil. lianocentofante@yahoo.com.br

${ }^{3}$ Universidade Federal de São Carlos, Programa de Pós-Graduação em Genética e Evolução. Rodovia Washington Luiz, 235 , 13565905 São Carlos, SP, Brazil. omfilho@power.ufscar.br 
Artoni \& Bertollo, 1999; Kavalco et al., 2005). According to Alves et al. (2003) and de Oliveira (2006), centric fusions are the main chromosomal rearrangement within Ancistrus, in which the reduction of diploid number seems to be an evolutionary trend. Nonetheless, other rearrangements, such as pericentric inversions and heterochromatin accumulation are also important for the chromosomal diversification and karyotype evolution of loricarids.

In the present work, cytogenetic analyses were carried out in different populations of seven Ancistrus species from three hydrographic basins in the state of Mato Grosso: Paraguay, Araguaia-Tocantins and Amazon.

\section{Material and Methods}

Cytogenetic studies were performed in 117 specimens from seven species of Ancistrus (Table 1) from three hydrographic basins in Mato Grosso State: Paraguay, Araguaia-Tocantins and Amazon basins. Voucher specimens were deposited in the Núcleo de Pesquisas em Limnologia, Ictiologia e Aquicultura, Universidade Estadual de Maringá, Paraná State, Brasil and identified by Dr. Claudio Zawadzki and coworkers (NUP 6827), and in the fish collection of the Museu de Ciências e Tecnologia da PUC-RS, Porto Alegre (PUC/RS), identified by Alexandre Cardoso and Tiago Carvalho (MCP 41969, 41973, 41974, 41976, 41977, 41978). Many of these are undescribed species and wait for a proper taxonomic description. The localities were georeferenced, approximately, according to I3geo map from Ministério do Meio Ambiente (MMA).
The technique for obtaining of mitotic chromosomes and conventional analysis followed Bertollo et al. (1978); Cbanding was performed to identify heterochromatic regions according to Sumner (1972); and the nucleolar organizer regions (Ag-NORs) were identified by silver nitrate staining (Ag-NORs) (Howell \& Black, 1980).

The chromosomes were organized into metacentric (m), submetacentric (sm), subtelocentric (st) and acrocentric (a), according to Levan et al. (1964).

\section{Results}

Different diploid numbers were observed among the analyzed species: $2 n=40$ to $2 n=54$ with karyotype formulae ranging from $\mathrm{FN}$ (Fundamental Number) $=80$ to $\mathrm{FN}=86$. The distinct diploid numbers, karyotype formulae and Ag-NOR locations are shown in Table 2.

Besides the variation shown in Table 2 and Fig. 2, the species from localities a to $\mathbf{f}$ presented small amount of heterochromatin as revealed by faint and reduced C-bands at interstitial and pericentromeric regions of some chromosomes. More evident heterochromatic blocks were detected only at the NOR-bearing pair in some metaphases. No cytogenetic differences were observed between males and females in these species based on conventional and C-banding analyses. An intraindividual polymorphism was observed in relation to NOR size, once larger and minor Ag-NOR marks were observed between homologues although all species presented single NORs with interstitial

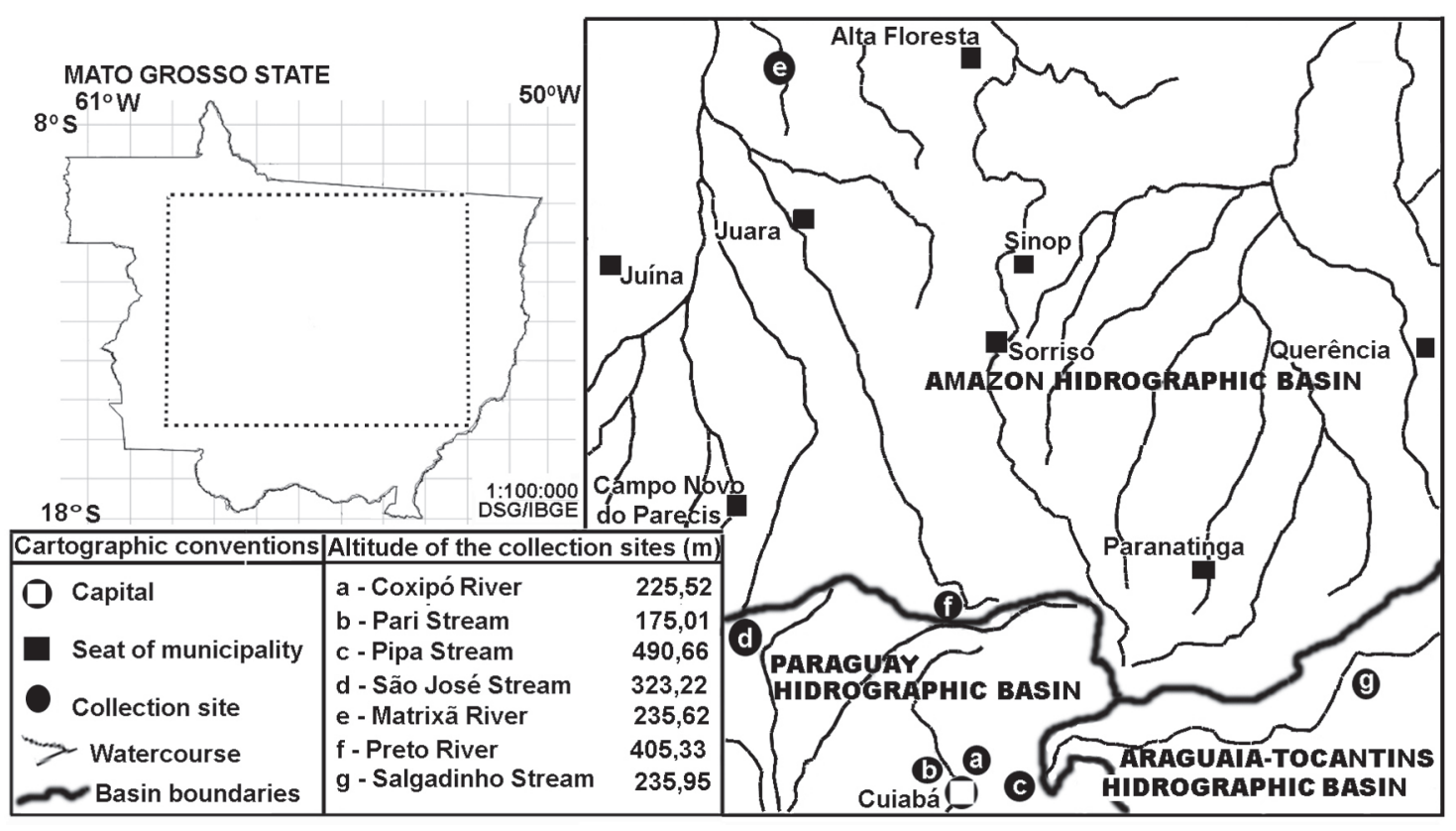

Fig. 1. Map of Mato Grosso State and sites crop (highlight-) showing Amazon, Araguaia-Tocantins and Paraguay hydrographic basins. Scale of original map 1:100.000. 
Table 1. Analyzed Ancistrus species with their respective hydrographic basins and locality. M: males, F: females.

\begin{tabular}{|c|c|c|c|}
\hline Basin/Specie & $\begin{array}{c}\text { Number of the } \\
\text { indivuduals }\end{array}$ & Locality/County & $\begin{array}{c}\text { Latitude and Longitude } \\
\text { approximately }\end{array}$ \\
\hline \multicolumn{4}{|l|}{ Paraguay } \\
\hline Ancistrus claro & $11 \mathrm{M}, 10 \mathrm{~F}$ & a. Coxipó River/Chapada dos Guimarães & $15^{\circ} 21^{\prime} \mathrm{S} 55^{\circ} 57^{\prime} \mathrm{W}$ \\
\hline Ancistrus sp. 03 & $6 \mathrm{M}, 6 \mathrm{~F}$ & b. Pari Stream /Cuiabá & $15^{\circ} 36^{\prime} \mathrm{S} 56^{\circ} 12^{\prime} \mathrm{W}$ \\
\hline Ancistrus sp. 01 & $6 \mathrm{M}, 7 \mathrm{~F}$ & c. Pipa Stream/Serra de São Vicente & $15^{\circ} 41^{\prime} \mathrm{S} 55^{\circ} 29^{\prime} \mathrm{W}$ \\
\hline Ancistrus sp. 04 & $12 \mathrm{M}, 15 \mathrm{~F}$ & d. São José Stream, Sepotuba River/Tangará da Serra & $\begin{array}{l}14^{\circ} 33^{\prime} \mathrm{S} 57^{\circ} 24^{\prime} \mathrm{W} \\
14^{\circ} 41^{\prime} \mathrm{S} 57^{\circ} 48^{\prime} \mathrm{W}\end{array}$ \\
\hline \multicolumn{4}{|l|}{ Amazon } \\
\hline Ancistrus sp. 06 & $9 \mathrm{M}, 5 \mathrm{~F}$ & e. Matrixã River/Nova Monte Verde & $10^{\circ} 03^{\prime} \mathrm{S} 57^{\circ} 36^{\prime} \mathrm{W}$ \\
\hline Ancistrus tombador & $8 \mathrm{M}, 5 \mathrm{~F}$ & f. Rio Preto/Diamantino & $15^{\circ} 02^{\prime} \mathrm{S} 56^{\circ} 13^{\prime} \mathrm{W}$ \\
\hline Araguaia-Tocantins Ancistrus sp. 13 & $11 \mathrm{M}, 6 \mathrm{~F}$ & g. Salgadinho Stream/Nova Xavantina & $14^{\circ} 40^{\prime} \mathrm{S} 52^{\circ} 21^{\prime} \mathrm{W}$ \\
\hline
\end{tabular}

and terminal sites (Fig. 2, box). In those species with higher diploid numbers, $2 \mathrm{n}=50$ to $2 \mathrm{n}=54$, a larger number of small acrocentric chromosomes was identified, hindering a defined analysis. The constitutive heterochromatin is scarce, with small and usually faint blocks after C-banding (Fig. 3 a-f).

The specimens of Ancistrus sp.13 from $\mathbf{g}$ site were highly differentiated from the others, with conspicuous heterochromatin blocks and reduced diploid number, $2 \mathrm{n}=40$ (Fig. $1 \mathrm{~g}$ and g'). In some individuals, the long arms of a large subtelocentric chromosome were nearly entirely heterochromatic while a small heterochromatin segment was observed in the homologue.

\section{Discussion}

Previous analysis in the genus Ancistrus reported a high chromosomal plasticity in relation to diploid number $(2 \mathrm{n}=34$, $38,40,42,44,46,48,50,52$, and 54); presence of five out of the seven sex chromosome systems known for freshwater fish, structural and morphology polymorphism in 18S rDNA and diversity 5S rDNA (Artoni \& Bertollo, 2001; Alves et al., 2003; Mariotto et al., 2004; Mariotto \& Miyazawa, 2006; de Oliveira et al., 2008; Mariotto et al., 2009; de Oliveira et al., 2009, Mariotto et al., 2011 and present study).

Ancistrus is characterized by a divergent karyotype evolution in contrast with other species within the tribe, such as species of the genera Baryancistrus, Peckoltia, Hemiancistrus, Panaque, Parancistrus, and Lasiancistrus (Artoni \& Bertollo, 2001; Souza, 2003; de Oliveira et al., 2006; Mariotto, 2009). It also differs from closely related taxonomic groups, like most species analyzed in the subfamily Hypoptopomatinae (Andreata et al., 1992, 1993, 2006) and in the tribe Pterygoplichthini (Alves et al., 2006).

Chromosomal and heterochromatic heteromorphisms, including XX/XY and ZZ/ZW sex chromosome systems, were identified in four out of the five Ancistrus species with cytogenetic studies for the Pantanal region (Mariotto et al., 2004; Mariotto \& Miyazawa, 2006).

According to Gold et al. (1990), a small amount of heterochromatin is a basal trait for teleosteans, including Siluriformes fishes. This statement supports the hypothesis that the karyotypes of Ancistrus from Paraguay basin presenting more heterochromatin segments and sex chromosome systems would be more derived, such as reported in Ancistrus cf. dubius (Mariotto et al., 2004; Mariotto \& Miyazawa, 2006), a species in which heterochromatinization of one chromosome in the heteromorphic pair seems to have played a major role in the fixation of sex chromosome systems. According Artoni \& Bertollo (1999) and Almeida-Toledo et al. (2001), the heterochromatin accumulation and changes in its distribution on chromosomes might favor the chromosomal heteromorphism and are usually associated with the origin of sex chromosomes in fish. However, in some Ancistrus species, the origin of sex chromosomes seems to be unrelated to constitutive heterochromatin, as observed in species from Amazon basin (de Oliveira et al., 2008).

Besides Ancistrus, other Loricariidae genera also present species with sex chromosome systems, such as Hypostomus (Michele et al., 1977; Artoni et al., 1998), Microlepidogaster and Pseudotocinclus (Andreata et al., 1992, 1993),

Table 2. Karyotype data of analyzed Ancistrus species in increasing diploid number order.

\begin{tabular}{cccccc}
\hline Specie & Locality & 2n & NF & Karyotypic formula & AgNORs \\
\hline & & & & & \\
Ancistrus claro, Ancistrus sp. 01, Ancistrus sp. 03 & a, b, c & 54 & 84 & $14 \mathrm{~m}, 8 \mathrm{sm}, 8 \mathrm{st}, 24 \mathrm{a}$ & $21^{\circ} \mathrm{a}$ \\
Ancistrus sp. 04 & d & 52 & 82 & $16 \mathrm{~m}, 8 \mathrm{sm}, 6 \mathrm{st}, 22 \mathrm{a}$ & $22^{\circ} \mathrm{a}$ \\
Ancistrus sp. 06 & e & 50 & 86 & $18 \mathrm{~m}, 10 \mathrm{sm}, 8 \mathrm{st}, 14 \mathrm{a}$ & $21^{\circ} \mathrm{a}$ \\
Ancistrus tombador & $\mathrm{f}$ & 50 & 84 & $14 \mathrm{~m}, 12 \mathrm{sm}, 8 \mathrm{st}, 16 \mathrm{a}$ & $20^{\circ} \mathrm{a}$ \\
Ancistrus sp. 13 & $\mathrm{g}$ & 40 & 80 & $30 \mathrm{~m}, 6 \mathrm{sm}, 4 \mathrm{st}$ & $18^{\circ} \mathrm{sm}$ \\
\hline
\end{tabular}


Loricariichthys (Scavone \& Júlio Jr., 1995), Hemiancistrus (de Oliveira et al., 2006) and Harttia (Centofante et al., 2006).

However, in the present study, the species located at higher altitude differed from those located in lower places and/or regions with high sediment flow. The cytotypes of species with $2 n=50,52$ and 54 chromosomes (Fig. 2) are in more elevated areas in relation to others, such as the rivers and streams from Tangará da Serra, Serra de São Vicente, Chapada dos Guimarães, and small tributaries from Amazon basin, northern Mato Grosso (Fig. 1); regarded as geomorphologic ancient areas when compared to Cuiabá depression and the region close to Nova Xavantina (see Ribeiro, 2006). The species

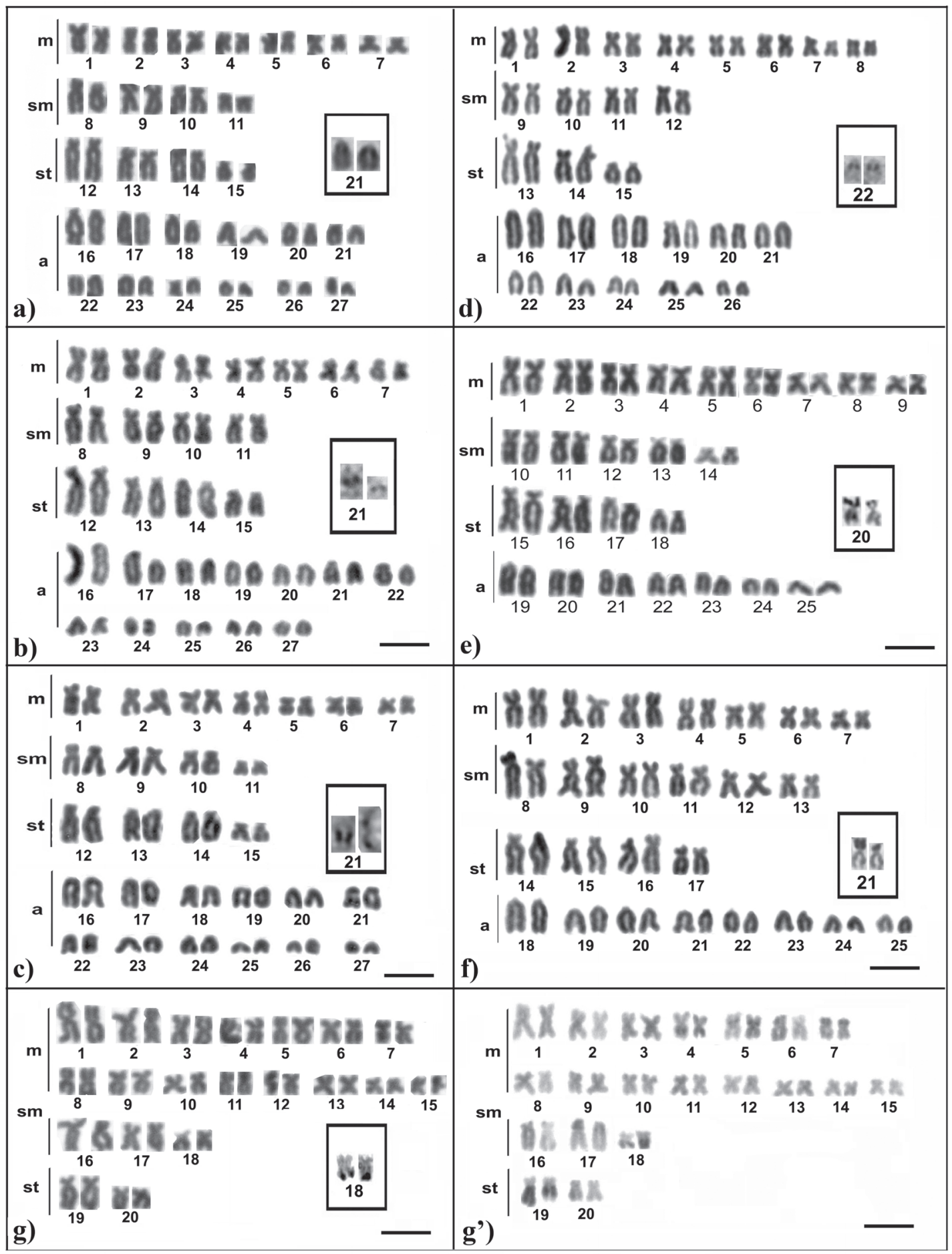

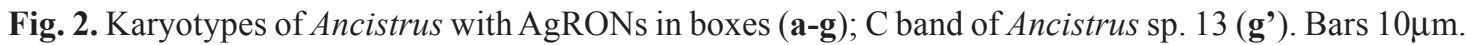


with $2 n=34,40$ and $2 n=42$ chromosomes occur in the Cuiabá depression, Nova Xavantina and Pantanal, areas susceptible to increased sedimentation (Mariotto \& Miyazawa, 2006; Mariotto et al., 2009). Most likely, the species with higher diploid numbers $(2 n=50$ to $2 n=54)$, bearing small amounts of heterochromatin and free from intraspecific polymorphism, are those characterized by plesiomorphic chromosomal features in the genus Ancistrus.

Chromosomal rearrangements, including fusions, pericentric inversions, transpositions, and heterochromatin accumulation, were probably responsible in determining the derived karyotypes, sex chromosomes systems and polymorphisms observed in species from Cuiabá depression. The chromosomal fusions and pericentric inversions are supported by the identification of fundamental numbers (FN) from 80 to 86 in the analyzed species, especially when species with striking differences in the diploid number are considered, such as Ancistrus claro $(2 \mathrm{n}=54)$ and Ancistrus sp. $13(2 \mathrm{n}=40)$.

The fixation of chromosomal changes in small and low vagile populations (Oliveira et al., 1988), as typical of most Loricariidae, is once again reported in species of the genus Ancistrus. The basal diploid number of $2 n=54$ chromosomes proposed for Loricariidae (Artoni \& Bertollo, 2001) seems to corroborate the inferences about the putative ancestor karyotype of $2 n=54$ chromosomes in the tribe Ancistrini, as observed in Ancistrus claro (present study) and in the genus Lasiancistrus (Mariotto, 2009), besides species from Hypoptopomatinae and
Pterygoplichthini, phylogenetically related to Ancistrini.

Armbruster (1997, 2004) places Ancistrus as the most phylogenetically derived genus in the subfamily. The chromosomal data obtained in the present work confirms this hypothesis once this genus is characterized by divergent karyotypes, regarding either chromosomal structure or diploid number, leading to higher karyotype diversity than other Ancistrini representatives.

Since species bearing multiple sex chromosomes (de Oliveira et al., 2008), as reported in Amazon basin, and simple sex chromosome systems have already been identified in Ancistrus (Mariotto et al., 2004; Mariotto \& Miyazawa, 2006; de Oliveira et al., 2006, 2007; Mariotto, 2009) according to each locality, a fixed pattern of sex heterogamety cannot be defined, thereby confirming the recurrence and the homoplasic character of sex chromosomes in the tribe Ancistrini.

The nucleolar organizer regions (NORs) in Ancistrus are highly conserved, comprising single marks in all species analyzed so far (Mariotto et al., 2004; Mariotto \& Miyazawa, 2006; de Oliveira et al., 2008; Mariotto et al., 2009 and present study) without any case of multiple NORs in the genus. The few cases of multiple NOR systems were reported in other genera and species of the tribe Ancistrini like Peckoltia sp. 1 and Peckoltia sp. 2 (Souza, 2003) and Hemiancistrus spilomma (de Oliveira et al., 2006).

Single NORs at interstitial position are putatively a primitive feature within Ancistrini, as proposed by Artoni \& Bertollo (2001),

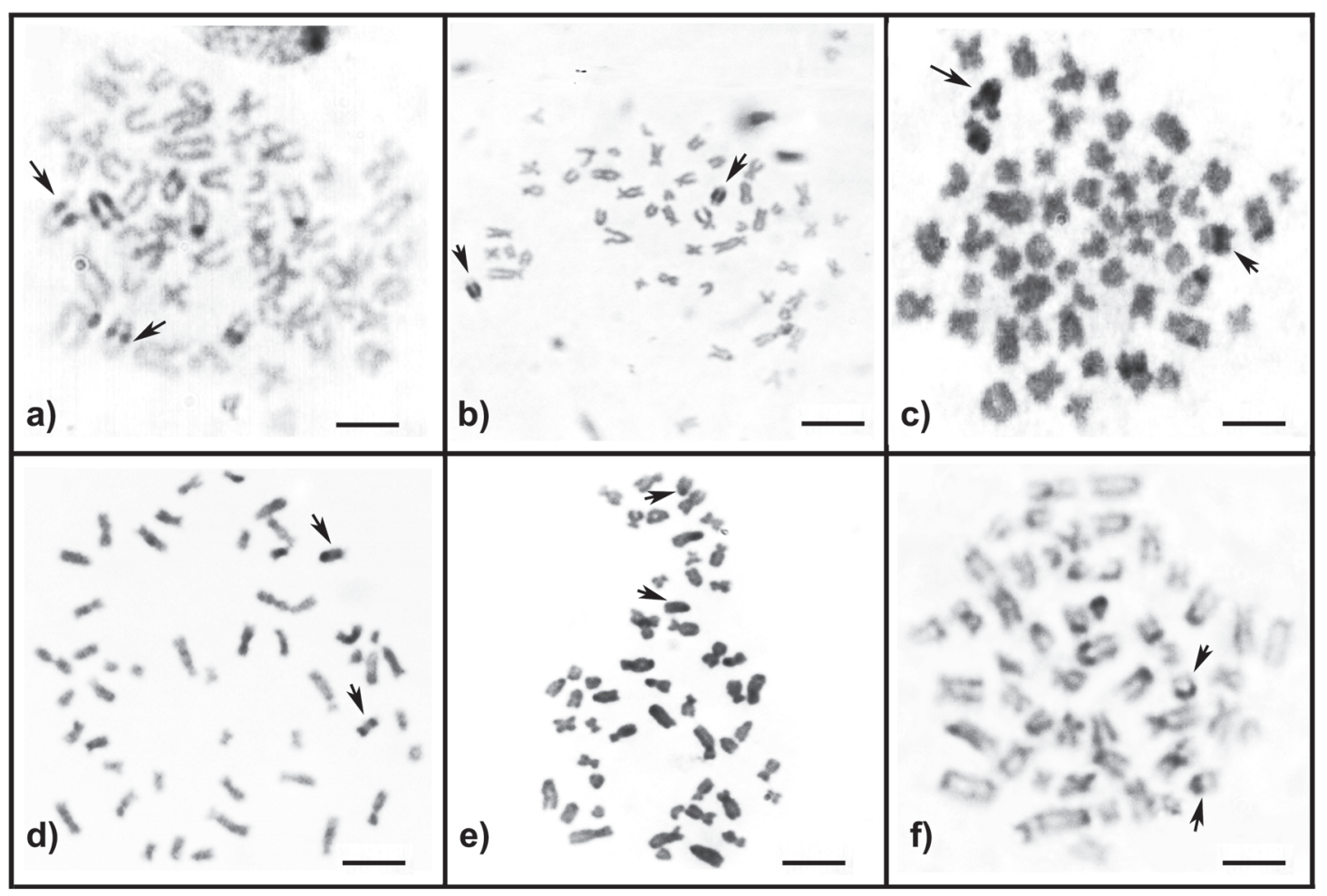

Fig. 3. Metaphases of Ancistrus with C band showing chromosomes NOR positive with large heterochromatin block (arrows). Bars $10 \mu \mathrm{m}$. 
Alves et al. (2003), Mariotto et al. (2004), Mariotto \& Miyazawa (2006), de Oliveira et al. (2006, 2007), Mariotto et al. (2009), Mariotto et al. (2011) and the present study. Nevertheless, NORs located at terminal position of chromosomes are observed in some species, as verified in Ancistrus n.sp. 2 and Ancistrus multispinnis (Alves et al., 2003); Hemiancistrus spinosissimus (de Oliveira et al., 2006); Ancistrus sp. "Piaguçu", Ancistrus sp. 1 "Balbina", Ancistrus sp. 2 "Barcelos" (de Oliveira et al., 2007); Ancistrus sp. 06, Ancistrus tombador, Lasiancistrus cf. schomburgkii, and Lasiancistrus sp. 1 (Mariotto, 2009 and present study). Most likely, the difference in NOR size verified in several species of the tribe Ancistrini is a feature related to a common ancestry, once it is shared by many taxa in the family Loricariidae. As for the chromosomal location, it corroborates the hypothesis of chromosomal rearrangements.

The present results show the remarkable plasticity in the genome organization of chromosomes in Ancistrus species from $2 \mathrm{n}=40$ to $2 \mathrm{n}=54$, that ultimately reflects their morphological plasticity, with representatives inhabiting fastflowing streams (plateau regions) up to flooded areas (plain regions), thus showing their adaptability to new niches. This evidence suggests speciation events once 13 cytotypes have already been reported in this group, which probably refer to new undescribed species.

\section{Acknowledgments}

The authors are grateful to Diones Krinski, Ronã Pinheiro Soares and Waldo Troy for the assistance during fish sampling in Tangará da Serra, Serra de São Vicente and Nova Xavantina and to professor Roberto Ferreira Artoni (UEPG) for the suggestions on the manuscript. Logistic and financial support to this work was provided by UFMT (Universidade Federal do Mato Grosso), CNPq (Conselho Nacional de Desenvolvimento Científico e Tecnológico) and FAPEMAT (Fundação de Amparo à Pesquisa do Estado de Mato Grosso).

\section{Literature Cited}

Almeida-Toledo, L. F. \& F. Foresti. 2001. Morphologically differentiated sex chromosomes in neotropical freswater fish. Genetica, 111: 91-100.

Alves, A. L., C. Oliveira \& F. Foresti. 2003. Karyotype variability in eight species of the subfamilies Loricariinae and Ancistrinae (Teleostei: Siluriformes: Loricariidae). Caryologia, 56: 57-63.

Alves, A. L., C. Oliveira, M. Nirchio, A. Granado \& F. Foresti. 2006. Karyotypic relationship among the tribes of Hypostominae (Siluriformes: Loricariidae) with description of $\mathrm{X} 0$ sex chromosome system in a Neotropical fish species. Genetica, 128: 1-9.

Andreata, A. A., L. F. Almeida-Toledo, C. Oliveira \& S. A.ToledoFilho. 1992. Chromosome studies in Hypoptomatinae (Pisces: Siluriformes: Loricariidae): I. XX/XY sex chromosome heteromorphism in Psudotocinclus tietensis. Cytologia, 57:369-372.

Andreata, A. A., L. F. Almeida-Toledo, C. Oliveira \& S. A ToledoFilho. 1993. Chromosome studies in Hypoptopomatinae (Pisces: Siluriformes: Loricariidae): II ZZ/ZW sex chromosome system, B chromosomes, and constitutive heterochromatin differentiation in Microlepidogaster leucofrenatus. Cytogenetics and Cell Genetics 63: 215-220.

Andreata, A. A., L. F. Almeida-Toledo, C. Oliveira \& S. A. ToledoFilho. 1994. Cytogenetic studies on the subfamily Hypoptopomatinae (Pisces: Siluriformes: Loricariidae). III. Analysis of seven species. Caryologia, 47: 27-37.

Andreata, A. A., C. Oliveira \& F. Foresti. 2006. Karyological characterization of four Neotropical fish species of the genus Hisonotus (Teleostei: Loricariidae: Hypoptopomatinae) from distinct Brazilian river basin. Genetics and Molecular Biology, 29: 62-66.

Armbruster, J. W. 1997. Phylogenetic relationships of the suckermouth armored catfishes (Loricariidae) with particular emphasis on the Ancistrinae, Hypostominae, and Neoplecostominae. Unpublished. Ph.D. Dissertation, University of Illinois, UrbanaChampaign, 409p.

Armbruster, J. W. 2004. Phylogenetic relationships of the suckermouth armored catfishes (Loricariidae) with emphasis on the Hypostominae and the Ancistrinae. Zoological Journal of the Linnean Society, 141: 1-80.

Artoni R. F., P. C. Venere \& L. A. C. Bertollo. 1998. A heteromorphic ZZ/ZW sex chromosome system in fish, genus Hypostomus (Loricariidae). Cytologia, 63: 421-425.

Artoni, R. F. \& L. A. C. Bertollo. 1999. Nature and distribution of constitutive heterochromatin in fishes, genus Hypostomus (Loricariidae). Genetica, 106: 209-214.

Artoni, R. F. \& L. A. C. Bertollo. 2001. Trends in the karyotype evolution of Loricariidae fish (Siluriformes). Hereditas, 134: 201-210.

Bertollo, L. A. C., C. S. Takahashi \& O. Moreira-Filho. 1978. Citotaxonomic considerations on Hoplias lacerdae (Pisces: Erythrinidae). Brazilian Journal of Genetics, 1: 103-120.

Burgess, W. E., 1989. An Atlas of freshwater and Marine catfishes: a preliminary survey of the Siluriformes. Canada. T.F.H. Publications.

Centofante, L., L. A. C. Bertollo \& O. Moreira Filho. 2006. Cytogenetic characterization and description of an XX/XY $\mathrm{Y}_{2}$ sex chromosome system in catfish Harttia carvalhoi (Siluriformes: Loricariidae). Cytogenetic Genome Research, 112: 320-324.

Ferraris Jr., C. J. 2007. Checklist of catfishes, recent and fossil (Osteichthyes: Siluriformes), and catalogue of Siluriform primary types. Zootaxa, 1418: 1-628.

Giuliano-Caetano, L. 1998. Polimorfismo cromossômico Robertsoniano em populações de Rineloricaria latirostris (Pisces: Loricariinae). Unpublished Ph.D Dissertation. Universidade Federal de São Carlos, São Carlos, São Paulo, $78 \mathrm{p}$.

Gold, J. R., C. Li, N. S. Shipley, P. K. Powers. 1990. Improved methods for working with fish chromosomes with a review of metaphase chromosome banding. Journal Fish Biology, 37: 563575.

Howell, W. M. \& D. A. Black. 1980. Controlled silver-staining of nucleolus organizer regions whit a protective coloidae developer: a 1-step method. Experientia, 36: 1014-1015.

Kavalco, K. F., R. Pazza, L. A. C. Bertollo \& O. Moreira-Filho. 2005. Karyotypic diversity and evolution of Loricariidae (Pisces: Siluriformes). Heredity, 94: 180-186.

Levan, A., K. Fredga \& A. A. Sandberg. 1964. Nomenclature for centromeric position on chromosomes. Hereditas, 52: 201220 . 
Mariotto, S., R. F. Artoni \& C. S. Miyazawa 2004. Occurence of sexual chromosome, of the type ZZ/ZW, in Ancistrus cf. dubius (Loricariidae: Ancistrinae) of the Paraguay River Basin, Mato Grosso, Brazil. Caryologia, 57: 327-331.

Mariotto, S. \& C. S. Miyazawa. 2006. Ancistrus cf. dubius (Siluriformes: Ancistrinae), a complex of species. 1. Chromosomal characterization of four populations and occurrence of sex chromosomes of the type XX/XY, in the Pantanal Basin of Mato Grosso, Brazil. Caryologia. 59: 299-304.

Mariotto, S., L. Centofante, C. S. Miyazawa, L. A. C. Bertollo \& O. Moreira Filho. 2009. Chromosome polymorphism in Ancistrus cuiabae Knaack, 1999 (Siluriformes: Loricariidae: Ancistrini). Neotropical Ichthyology. 7: 595-600.

Mariotto, S., L. Centofante, R. F. Artoni, M. R. Vicari \& O. Moreira Filho. 2011. Chromosomal diversification in ribosomal DNA sites in Ancistrus species (Loricariidae: Ancistrini) from three hydrographic basins of Mato Grosso, Brazil. Comparative Cytogenetics, 5: 289-300.

Mariotto, S. 2009. Estudo citogenético clássico e molecular em quinze espécies da tribo Ancistrini (Siluriformes, Loricariidae) de três bacias hidrográficas brasileiras. Unpublished Ph. D. Dissertation, Universidade Federal de São Carlos, São Carlos, SP, 101p.

Michelle, J. I., C. S. Takahashi \& I. Ferrari. 1977. Karyotypic studies of some species of the family Loricariidae (Pisces). Cytologia, 42: 539-546.

Oliveira, C., L. F. Almeida-Toledo, F. Foresti, H. A. Britski \& S. A. Toledo-Filho. 1988. Chromosome formulae of neotropical freshwater fishes. Brazilian Journal Genetic, 11: 577-624.

de Oliveira, R. R., I. L. Souza \& P. C. Venere. 2006. Karyotype description of three species of Loricariidae (Siluriformes) and ocurrence of the ZZ/ZW sexual system in Hemiancistrus spilomma Cardoso \& Lucinda, 2003. Neotropical Ichthyology, 4: 93-97. de Oliveira, R. R., E. Feldberg, M. B. Anjos \& J. Zuanon. 2007. Karyotype characterization and ZZ/ZW sex chromosomes heteromorphism in two species of the catfish genus Ancistrus Kner, 1854 (Siluriformes: Loricariidae) from the Amazon basin. Neotropical Ichthyology, 5: 301-306.

de Oliveira, R. R., E. Feldberg, M. B. Anjos \& J. Zuanon. 2008. Ocurrence of multiple sexual chromosomes $\left(X X / X_{1} Y_{2}\right.$ and $\mathrm{Z}_{1} \mathrm{Z}_{1} \mathrm{Z}_{2} \mathrm{Z}_{2} / \mathrm{Z}_{1} \mathrm{Z}_{2} \mathrm{~W}_{1} \mathrm{~W}_{2}$ ) in catfishes of the genus Ancistrus (Siluriformes: Loricariidae) from the Amazon Basin. Genetica, 134: 243-249.

Ribeiro, A. C. 2006. Tectonic history and the biogeography of the freshwater fishes from de coastal drainages of eastern Brazil: an example of faunal evolution associated with a divergent continental margin. Neotropical Ichthyology, 4: 225-246.

Scavone, M. D. \& H. F. Julio Jr. 1995. Cytogenetics analysis and heterochromatin distribution in ZZ/ZW sex chromosomes of the mailed catfish Loricariichtys platymetopon (Loricariidae: Siluriformes). Brazilian Journal of Genetics, 18: 31-35.

Souza, A. C. P. 2003. Descrição cariotípica de peixes dos gêneros Baryancistrus, Parancistrus, Peckoltia e Ancistrus (Ancistrinae: Loricariidae) da Bacia Amazônica. Unpublished Ph.D. Dissertation. Universidade Federal do Pará/Museu Paraense Emílio Goeldi. Pará, 130p.

Sumner, A. T. 1972. A simple technique for demonstrating centromeric heterochromatin. Experimental Cell Research, 75: 304-306.

Submitted October 31, 2011 Accepted August 10, 2012 by Claudio Oliveira Published March 31, 2013 